\title{
Research on Eco-friendly Alkali Activated Concrete Incorporating Industrial Wastes
}

\author{
Shriram Marathe, Mithanthaya I R., Sahithya S. Shetty
}

\begin{abstract}
In the present scenario, the production of green and sustainable concrete has become a must to substitute the ordinary Portland cement (OPC) concrete. It is an eminent fact that the manufacture of OPC requires burning of its raw materials which lead to a huge amount of carbon dioxide liberation; thus it requires a large amount of energy dissipation. The concrete produced using alkali activation has become renowned methods to replace the conventional $\mathrm{OPC}$, which gives an answer to find a way to produce environmentally friendly concrete. In the current study, the alkaline activator used to activate the binder was sodium hydroxide solution dispersed in liquid sodium silicate. The utilization of industrial dissipate materials such as GGBS, fly ash, and waste glass powder was used as the binding ingredients, and stone crusher dust was used as fine aggregates. The experimental investigation showed that a quality concrete can be easily produced using alkali activation of industrial wastes satisfying its strength requirements. The statistical models developed shown that there is a significant relationship between various cube and cylinder strengths. Thus alkali-activated concrete $(A A C)$ can effectively reduce the environmental hazards associated with OPC concrete, which also provides an effective way of utilizing major industrial byproducts.
\end{abstract}

Index Terms: Sustainable Concrete; Alkali-activation; Compressive Strength; Glass powder; Statistical Model.

\section{INTRODUCTION}

In the construction field, concrete is the most extensively used material and it has a wide range of application. In India, a developing country, the rate of construction is increasing rapidly. Due to such increased construction, there is a huge pressure on the cement industry to satisfy the large demand for Ordinary Portland Cement (OPC). But the rate of manufacture of OPC has decreased due to the limited availability of the raw material like limestone. It is reported that by 2020 , in India, the total demand for cement will reach 550 million tons with a shortage of 230 million tons which is approximately 58\%[1]. The yearly global creation of Portland-cement is in excess of $1000 \mathrm{M}$ tons, whereas the yield of the industrial waste materials which can be rightfully used as cementing substitute materials. The scope for the use of industrial wastes as a cementing substitute material in producing concrete are slags, fly ashes, rice husk ash, silica fumes, etc. It is a well-known reality that the production of cement leads to an enormous amount of liberation of carbon dioxide to the atmosphere[2]. As of now, the majority of

Shriram Marathe, Research Scholar and Assistant Professor, Department of Civil Engineering, NMAM Institute of Technology, Nitte, India.

Mithanthaya I R, Professor, Department of Civil Engineering, NMAM Institute of Technology, Nitte, India.

Sahithya S. Shetty, M. Tech Scholar, Department of Civil Engineering, NMAM Institute of Technology, Nitte, India.
Revised Manuscript Received on July 18, 2019

waste materials were used as pozzolanic binders, aggregates or fillers in concrete production. The fly ash and ground granulated blast furnace slag (GGBS) are the best examples for such pozzolanic materials. The research for the new environmental friendly i.e., sustainable construction material which will match the durability of early concrete has roused interest into the study of the alkali-activated cementitious method over the last few years[3]. Alkali-activated concrete(AAC) is a novel construction substance which can be created by the chemical action of inorganic fragments. The materials rich in alumina and silica respond with alkaline solution forms alumina-silicate gel which act as a binder for the generation of concrete. This is a brilliant alternative building material to the existing OPC based cement concrete. Another major industry by product is the waste glass, whose disposal is also a major existing problem worldwide. The waste glass is a headache for the municipalities. The attempt can be made to solve this burning problem by utilizing this waste glass by re-using it as a cementing substitute ingredients in producing concrete. Utilization of waste glass as a binding material in producing concrete had shown some significant positive results[4][5][6]. Du and Tan [7] studied the behavior of OPC based concrete replaced with glass powder; In this paper, the study was conducted by replacement of OPC up to $60 \%$ by glass powder. The study also revealed that to produce high-performance concrete, $15 \%$ glass powder usage is significant. Some studies on the utilization of the glass in producing alkali-activated concrete were also shown a promising response on the concrete properties, where the powdered glass has used as a partial replacement with binder[8]. Mithanthaya et al [8] conducted an intensive study and could successively produce a concrete of grade up to M-40 without using OPC as binder; in their study they have used alkali activated GGBS, fly-ash, and powdered glass as binders in producing concrete which clearly indicate a scope of usage of glass powder as a binding agent for producing alkali-activated concrete.

To produce any conventional concrete, the river sand is the most popular choice to be used as a fine aggregate ingredient. The overuse of this material has led to ecological concerns, the reduction of safe river-sand deposits and an attendant cost increase for the material. Thus, it is enviable to find out a cheap, environmentally friendly substitutes for the conventional river sand which are preferably industrial byproduct or waste materials. In the present work, quarry stone dust is used as a total replacement for conventional fine aggregates (river sand). Quarry stone dust can be described as remainder, tailing or other non-valuable by-product material

Published By:

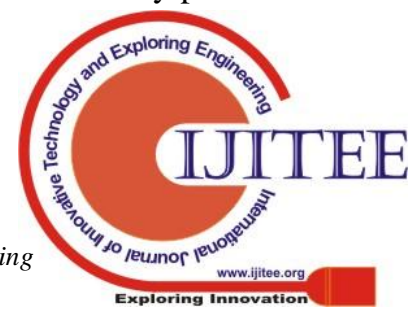




\section{WASTES}

after the extraction and processing crushed stone coarse aggregate of a variety of sizes. Once the big quarry boulders are broken into tiny pieces, this quarry stone dust is obtained. This quarry stone dust is grayish in shade. Thus, quarry dust can be treated as a industrial by-product material procured as a result of the extraction of stone coarse aggregates. There is a lot of literature regarding the utilization of quarry dust in place of conventional river sand as fine aggregates in the concrete applications. Ilangovana et al.[9] conducted a study on the feasibility of the usage of crusher dust as hundred percent substitute for fine aggregate in conventional concrete. The test conducted were to investigate the behavior of the concrete in compression, and flexural strengths. They found that the strength of crusher dust concrete is comparatively 1012 percent more than that of a similar mix prepared with river sand based conventional cement concrete. Adams et al[10], studied the effect of graded crushed stone dust as fine sand with fibers and established that the flexural strength was more than the concrete with natural sand; the study also depicted the manufacture of high-performance concrete (HPC) using stone crusher dust materials. Sumit et al.[11], conducted a study on limited replacement of conventional sand with stone quarry dust material in ordinary concrete. They found an upgradation in compressive strength, but it affected the desired workability - leading to a decrease in workability value with an increase in the increased amount of dust. Adding up of fly ash in minute quantity proved to pick up the workability.

Taking into account the above facts from the literature work, a laboratory exploration was planned to study the fresh and hardened properties of concrete produced using alkali-activated concrete. This concrete was produced with available industrial ravage materials such as GGBS, waste glass powder, fly ash, and activating using sodiumhydroxide dissolved in sodium silicate solution as activators. The concrete specimens were cured at room temperature. Generally, alkali-activated concrete is cured under high temperature to get increased strength in a short period which involves additional cost and input of additional energy. Hence, the gain in the strength due to air curing of this concrete under room temperature only was considered in the present study.

\section{EXPERIMENTAL METHODOLOGY}

The materials used to produce alkali activated concrete are discussed in the following section. The Ground Granulated Blast Furnace Slag (GGBS) used for this experimental work had a specific gravity of 2.89, and fineness in the range of $400-600 \mathrm{~m}^{2} / \mathrm{Kg}$. The ASTM Class $\mathrm{F}$ type fly-ash was procured from local thermal power plant. The material was greyish white in colour had a specific surface area in the range $290-350 \mathrm{~m}^{2} / \mathrm{Kg}$, the specific gravity of 2.16. A finely grounded glass was also used in the present investigation as a binding ingredient. The locally available waste building glass collected, cleaned and then powdered. The resultant glass powder was fair in color, which had a specific gravity of 2.45.and. The locally available stone quarry dust passing $4.75 \mathrm{~mm}$ IS sieve with a specific gravity of 2.60, classified as zone II as per IS-383 [12]. The fineness modulus of this aggregate was found to be 4.23 . The locally available crushed stones of specific gravity of 2.70 passing through $20 \mathrm{~mm}$ IS sieve is used as the coarse aggregates. The laboratory water was used to produce concrete.

The alkaline solution consists of solid sodium hydroxide crystals $(\mathrm{NaOH})$ with $98 \%$ purity and liquid Sodium silicate solution. Both the ingredients are purchased from local commercial suppliers. The alkaline solution was prepared by preparing the aqueous solution consisting the required amount of $\mathrm{NaOH}$ crystals in sodium silicate solution and water. The alkali deliberation of the activator is an elementary need for improving the perfunctory properties of binding ingredients i.e., GGBS, fly-ash, and glass powder.

A M-40 mix design was made using the conventional Indian method (IS-10262 2009[13]) and the same was modified according to the available literature to obtain the mix design for AAC [14]. From the available literature, the mix is prepared for AAC with activator modulus 1.25. The amount of activator used is $4 \%$ of the binding material, which was kept constant throughout the work. The amount of alkaline activator used was kept steady to preserve an activator modulus of 1.25 throughout the investigation. The water-binder ratio was kept maintained at 0.40 . Two types of specimens were cast, one with $0 \%$ glass powder (denoted by Mix M-0) and one more with $25 \%$ glass powder (denoted by Mix M-25). In $0 \%$ glass powder mix, the $25 \%$ fly-ash was used; whereas in $25 \%$ glass powder mix, $0 \%$ fly-ash is used. The major binder material was GGBS which was kept at a dosage of $75 \%$ in the binder, which was kept constant in both the mixes. The calculated amount of fly ash, GGBS, glass powder, and aggregates are thoroughly dry mixed in a blender. Then alkaline activator is added to the dry mix. which is then mixed together to form a uniform mixture. The constituents are mixed meticulously until a homogeneous consistency was attained. Standard test specimens were cast for a study of the performance. All the cast specimens were air cured in laboratory condition prior to testing.

All the castings are done at the new research laboratory in the Civil Engineering Department of NMAMIT Nitte. The testing of the specimens was done in the department concrete laboratory. The casting of the specimens, kept for air curing and testing is shown in Fig 1 to 2 . In the present investigation, the early age properties and gain in the strength of alkali-activated cement based concrete are studied for both cylinder and the standard cubes. Also, the statistical relationship connecting the cube strength and cylinder strength of this alkali activated concrete is developed based on the laboratory test results.

The cube specimens and the cylinder specimens were tested after air curing for their compressive strength at different ages starting from 3 days till 28 days. The specimens are subjected to air curing in the research laboratory. The cube specimens were de-molded after 24 hours of its casting, whereas cylinder specimens were de-molded after 48 hours of casting. Figure 2 also shows the failure pattern of both cube and cylinder specimens under gradually applied compressive load. The testing was done as per the standards suggested by BIS. 


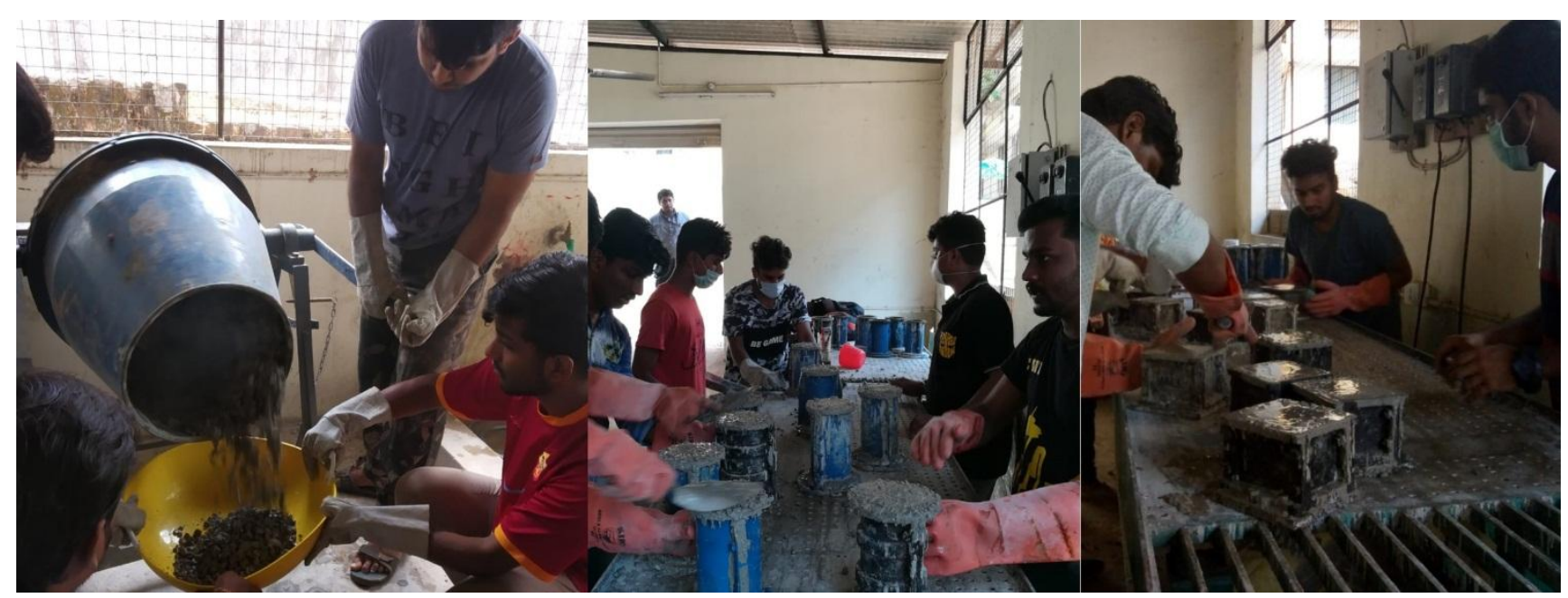

Fig. 1: Mixing of Concrete, Filling the standard molds and Vibratory Compaction for Casting of test specimens

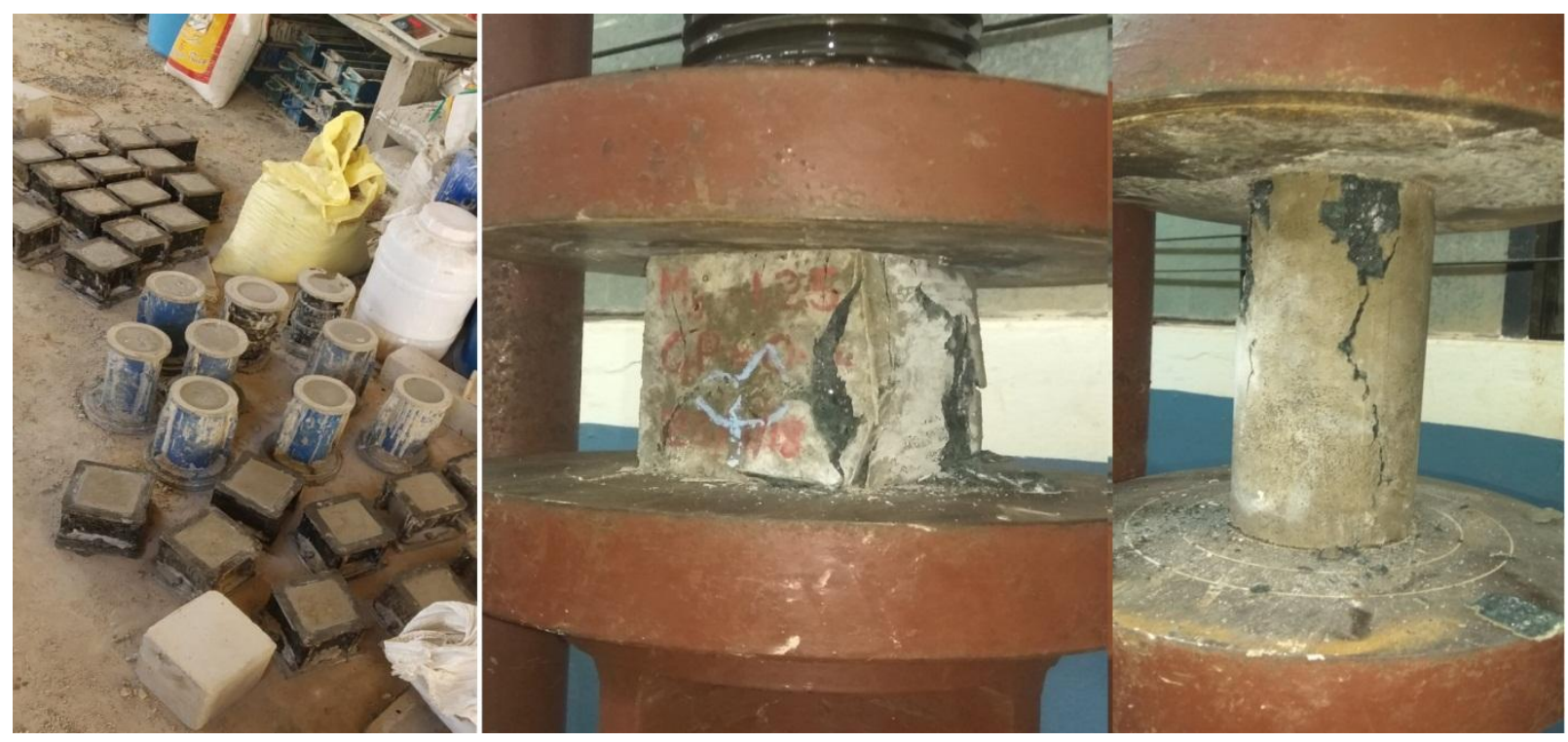

Fig. 2: Air curing in the laboratory, the typical mode of failure of cube and cylinder specimens under compression

\section{RESULTS AND DISCUSSIONS}

In both the cases (M-0 and M-25) the density of the concrete was found to be on an average $2398 \mathrm{~kg}$ per cubic meter (almost equal to $2400 \mathrm{~kg}$ per cubic meter), which is almost same as that of OPC based concrete as per IS:4562000 [15] guidelines. The water absorption of AAC concrete was found to be within the desirable limits by BIS. The slump of fresh AAC was not of so much significance since the mix-design was done to produce pavement quality concrete. The compressive strength test on cube and cylinder specimens were carried out as per IS-516:1959 [16]. The test results for both the mixes (M-0 and M-25) for the ages 3 days, 7 days, 14 days, 21 days and 28 days of air curing is shown in figure 3 and figure 4 respectively. The conventional OPC based concrete of laboratory design strength M-40 will show a 28 days compressive strength (cube strength) of about $49 \mathrm{MPa}$ (target strength); whereas the alkali activated concrete is showing a 28 day strength of about $60 \mathrm{MPa}$. Thus, it can be stated that the compressive strength gained in alkali activated concrete will be much higher compared with conventional OPC binder based concrete.

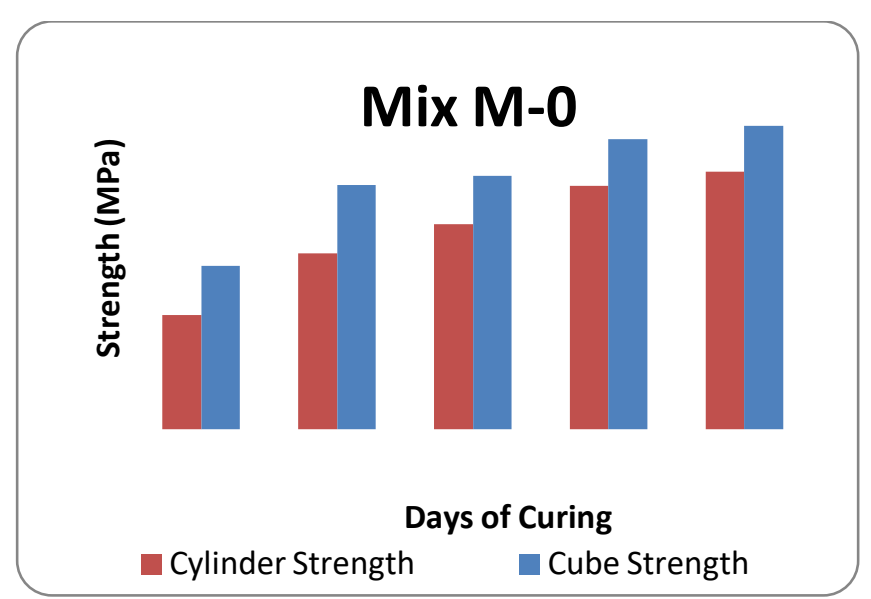

Fig. 3: Compression test results for standard cube and cylinder specimens for M-0 mix 


\section{RESEARCH ON ECO-FRIENDLY ALKALI ACTIVATED CONCRETE INCORPORATING INDUSTRIAL WASTES}

Figure 3 and 4 shows that there is an early gain in strength till the age of 7 days and thereby gradual gain of strength from 7 days till 28 days cylinder strength was comparatively less while compared with the cube strength. The difference was noted which is equivalent to that of OPC. For M-0 mix, more than $50 \%$ of the 28 -day cube strength was achieved at 3 days itself. The 28-day strength of $67 \mathrm{MPa}$ was achieved for M-0 mix. Due to the inclusion of glass powder, the initial gain in strength was observed to be less than that of M-0 mix. For the M-25 mix, about $37 \%$ 28-day strength was marginally greater for M-25 mix. A cube strength of $68 \mathrm{MPa}$ was achieved at 28 days for M-25 mix.

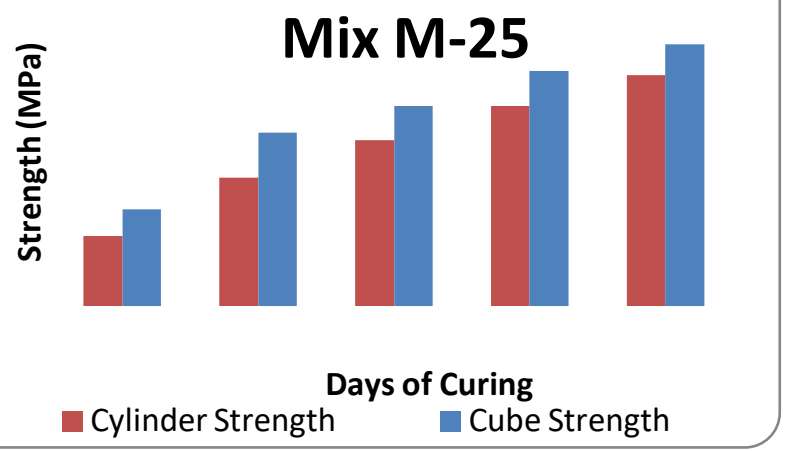

Fig. 4: Compression test results of standard cube and cylinder specimens for M-25 mix

The cylinder strength in both cases was marginally less while compared with that of the corresponding cube strengths at every stage of curing. In the case of cylinders, the percentage gain in strength and the early strength gain was almost the same as that of the cube specimen results. In conventional OPC based concrete, the cylinder compressive strength will be almost equal to $80 \%$ of that of the cube compressive strength. But, for the alkali activated concrete, from the results obtained, it can be stated that the 28 days cylinder compressive strength is almost $90 \%$ of that of the cube strength.

The statistical analysis of the laboratory test results was done using a statistical package. The correlation between sample cylinder compressive strength and cube compressive strength is shown in figure 5 for M-0 mix; and for M-25 mix, it was shown in figure 6 .

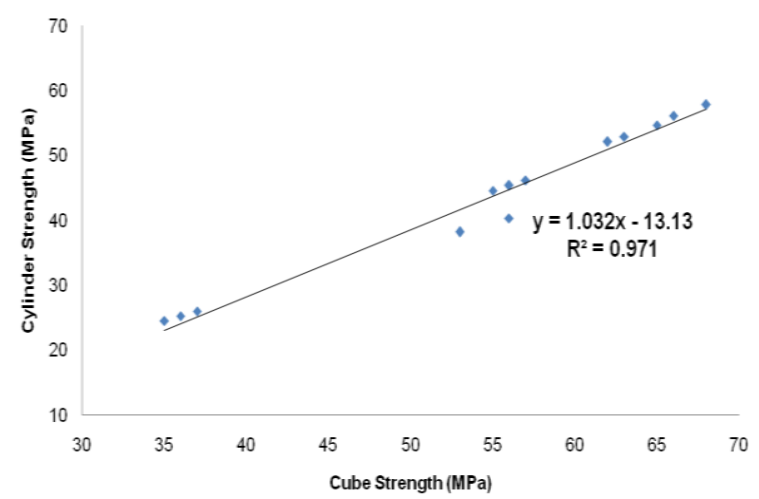

Fig. 5: Relationship between Compression test results of standard cube and cylinder specimens for M-0 mix of the 28-day cube strength was achieved at 3 days. But the

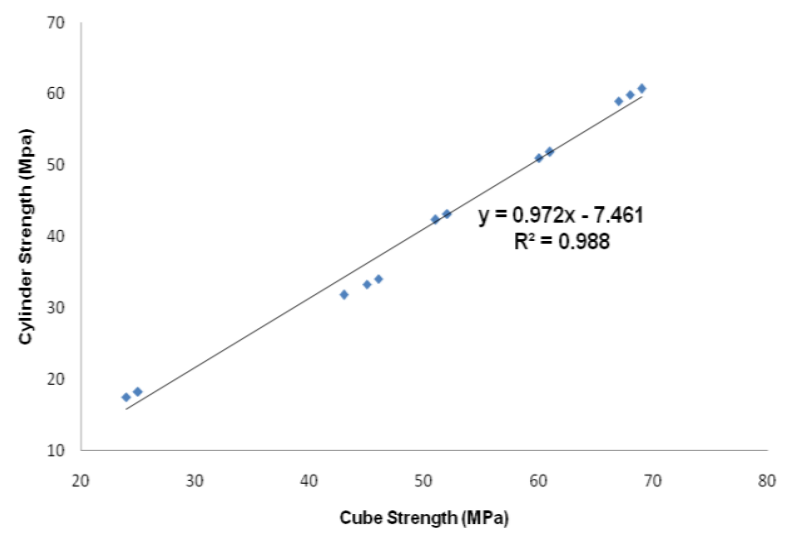

Fig. 6: Relationship between Compression test results of standard cube and cylinder specimens for M-25 mix

For the statistical analysis, randomly 15 sample observations of cube and cylinder compressive strength results were taken. The regression parameters after the statistical analysis for M-0 and M-25 mix are shown in table 1. The ANOVA table for M- 0 mix is shown in Table 2 and for M-25 mix is shown in Table 3 respectively.

Table 1: Regression parameters on compressive strength of cube and cylinders for both M-0 and M-25 mix

\begin{tabular}{lll}
\hline Regression Statistics & & \\
\hline Particular & M-0 Mix & M-25 Mix \\
Multiple R & 0.986 & 0.994 \\
R Square & 0.971 & 0.988 \\
Adjusted R Square & 0.969 & 0.988 \\
Standard Error & 2.039 & 1.680 \\
Observations & 15 & 15 \\
\hline
\end{tabular}

Usual Indian tendency is to conduct compression test on cube samples. In the present study, the compressive strength of cylinder specimen is considered as the dependent variable (x) and compressive strength of cube was considered as an input-independent variable (y). The correlation equations are shown in figure 5 and 6 . Thus to predict the compressive strength of the cylinders, the above correlation can be adopted. The study was conducted on alkali-activated concrete mixes. Thus this study would be more reliable on alkali-activated concrete.

In both the cases, the R-square value was obtained was greater than 0.95 (almost near to 1.0), which simply indicates that there is a good correlation linking the cube strength with cylinder strength values. Here in-addition, from the first principles of generating any statistical models, there are certain requirements to satisfy to state it as a best (ideal) statistical model- such as a high $\mathrm{R}^{2}$ value, a low standard error value, a high value of $\mathrm{F}$-test for independence of variables, a lower t-test for significance of intercept, a high value of t-test for significance of independent variables, and a reasonable magnitude of coefficients. 
It is also clear from the requirements that, the regressions with lesser number of variables and simpler functions must be given preference; and regressions with high negative coefficients must be avoided. From the present study, all the ANOVA parameters for the developed model indicated in Table 2 and 3 show that the developed models are satisfying the most of the requirement of an ideal statistical model. Thus, the statistical models developed can be said to be good models to predict the unknown i.e., if the cylinder compressive strength is known, we can predict the cube compressive strength of AAC specimens; and vice-versa.

Table 2: ANOVA results on compressive strength of cube and cylinders for $\mathrm{M-0}$ mix

\begin{tabular}{|l|r|r|r|r|r|}
\hline \multicolumn{1}{l|}{ ANOVA - M-0 Mix } \\
& df & \multicolumn{1}{c|}{ SS } & MS & F & $\begin{array}{r}\text { Significance } \\
\text { F }\end{array}$ \\
\hline Regression & 1 & 1836.047 & 1836.047 & 441.588 & 0.000 \\
Residual & 13 & 54.052 & 4.158 & & \\
Total & 14 & 1890.099 & & & \\
\hline
\end{tabular}

\begin{tabular}{lrrrrrrrr}
\hline & \multirow{2}{*}{ Coefficients } & $\begin{array}{c}\text { Standard } \\
\text { Error }\end{array}$ & \multirow{2}{*}{ Stat } & $\begin{array}{c}\text { P- } \\
\text { value }\end{array}$ & $\begin{array}{c}\text { Lower } \\
95 \%\end{array}$ & $\begin{array}{r}\text { Upper } \\
95 \%\end{array}$ & $\begin{array}{r}\text { Lower } \\
95.0 \%\end{array}$ & $\begin{array}{r}\text { Upper } \\
95.0 \%\end{array}$ \\
\hline Intercept & -13.131 & 2.763 & -4.753 & 0.000 & -19.099 & -7.162 & -19.099 & -7.162 \\
X Variable 1 & 1.032 & 0.049 & 21.014 & 0.000 & 0.926 & 1.139 & 0.926 & 1.139 \\
\hline
\end{tabular}

Table 3: ANOVA results on compressive strength of cube and cylinders for $\mathrm{M}-25 \mathrm{mix}$

\begin{tabular}{|c|c|c|c|c|c|}
\hline \multicolumn{6}{|c|}{ ANOVA - M-25 Mix } \\
\hline & df & SS & MS & $\mathrm{F}$ & $\begin{array}{c}\text { Significance } \\
\text { F }\end{array}$ \\
\hline Regression & 1 & 3136.948 & 3136.948 & 1111267 & 0000 \\
\hline Residual & 13 & 36.697 & 2.823 & $1111.20 /$ & 0.000 \\
\hline Total & 14 & 3173.645 & & & \\
\hline
\end{tabular}

\begin{tabular}{|c|c|c|c|c|c|c|c|c|}
\hline & Coefficients & $\begin{array}{l}\text { Standard } \\
\text { Error }\end{array}$ & t Stat & $\begin{array}{c}\text { P- } \\
\text { value }\end{array}$ & $\begin{array}{c}\text { Lower } \\
95 \%\end{array}$ & $\begin{array}{c}\text { Upper } \\
95 \%\end{array}$ & $\begin{array}{l}\text { Lower } \\
95.0 \%\end{array}$ & $\begin{array}{l}\text { Upper } \\
95.0 \%\end{array}$ \\
\hline Intercept & -7.461 & 1.517 & -4.917 & 0.000 & -10.739 & -4.183 & -10.739 & -4.183 \\
\hline X Variable 1 & 0.972 & 0.029 & 33.336 & 0.000 & 0.909 & 1.035 & 0.909 & 1.035 \\
\hline
\end{tabular}

\section{CONCLUSION}

The key conclusions of the present laboratory investigation and statistical investigations carried out on the strength performance of alkali-activated concrete specimens are summarised here. The compressive strength of alkali activated mixes produced using industrial waste materials show a significant scope for further study towards replacing the conventional OPC based concrete applications. The strengths are very high compared with similar mixes produced using OPC based concrete. The early gain in strength is also good when compared with its counterpart. However, the AAC produced using glass powder shown a little smaller gain in strength when compared to the slag-flyash based mix, but the 28-day strength gain is almost similar. Thus usage of glass powder also shown a promising future as an alternative binder material in producing AAC of desired strength. For, alkali activated concrete, it can be stated that the 28 days cylinder compressive strength is almost $90 \%$ of that of the cube strength, which is greater than that of OPC based concrete. The statistical models developed between the cube compressive strength and cylinder compressive strength were showing good positive linear correlation. These models could be used in predicting the unknown strength, provided one strength is known. However, the experimental investigations were extended to study the tensile behavior by subjecting the specimens to bending and split tension test. The durability aspects of this alkali-activated concrete can also be subjected to acid and sulfate environment. The investigation is yet to complete. If the outcomes are positive, it can be confidently stated that the slag-fly ash-glass powder based alkali-activated concrete will successfully be utilized as a sustainable and environmentally gracious alternative material for normalconventional concrete formed utilizing ordinary Portland cement as the binder.

\section{ACKNOWLEDGMENT}

Every concrete specimen was prepared in the newresearch laboratory of the Civil Engineering Department, NMAM Institute of Technology, Nitte. Authors wish to express their gratitude to the authorities of the institution for the permission and encouragement provided during the investigation. Financial support provided by Nitte Education Trust i.e., NMAMIT research fund on the project entitled "Study and to Develop Cost-Effectively and Green Masonry Block Using Industrial Waste Materials" is gratefully acknowledged. The authors furthermore wish to thank the

Published By: 


\section{WASTES}

final year B.E. Civil Engineering students of NMAM Institute of Technology namely, Rahul Shenoy Y, Pradeep Kumar, Naveena N, Arjun KB, Susmitha S K, and Vanishree $\mathrm{K}$ for their support in effectively conducting the experimental works.

\section{REFERENCES}

1. B. Singh, G. Ishwarya, M. Gupta, and S. K. Bhattacharyya, "Geopolymer concrete: A review of some recent developments," Construction Building Material, vol. 85, pp. 78-90, 2015.

2. E. Gartner, "Industrially interesting approaches to " "low- $\mathrm{CO}_{2}$ cements" vol. 34, no. January 2004, pp. 1489-1498, 2010.

3. Y. Ding, J. Dai, and C. Shi, "Mechanical properties of alkaliactivated concrete: A state-of-the-art review," Construction Building Material, vol. 127, pp. 68-79, 2016.

4. G. M. S. Islam, M. H. Rahman, and N. Kazi, "Waste glass powder as partial replacement of cement for sustainable concrete practice," International Journal of Sustainable Built Environment, vol. 6, no. 1, pp. 37-44, 2017.

5. G. Vijayakumar, M. H. Vishaliny, and D. Govindarajulu, "Studies on Glass Powder as Partial Replacement of Cement in Concrete Production," vol. 3, no. 2, pp. 153-157, 2013.

6. S. Marathe, I. R. Mithanthaya, and S. Shetty, Strength behaviour of masonry blocks produced using green concrete, Sustainable Construction and Building Materials. Lecture Notes in Civil Engineering, vol 25. pp 33-40. Springer, Singapore. 2019.

7. H. Du and K. H. Tan, "Waste Glass Powder as Cement Replacement in Concrete Waste Glass Powder as Cement Replacement in Concrete," Journal of Advanced Concrete Technology, vol. 12, pp. 468-477, 2015.

8. I. R. Mithanthaya, S. Marathe, N. B. S. Rao, and V. Bhat, "Influence of superplasticizer on the properties of geopolymer concrete using industrial wastes," Material Today: Proeedings, vol. 4, no. 9, pp. 9803-9806, 2017.

9. R. Ilangovana, N. Mahendrana, and K. Nagamanib, "Strength and durability properties of concrete containing quarry rock dust as fine aggregate," vol. 3, no. 5, pp. 20-26, 2008.

10. M. A. Joe, A. M. Rajesh, P. Brightson, and M. P. Anand, "Experimental Investigation on The Effect Of M-Sand In High Performance Concrete," no. 12, pp. 46-51, 2013.

11. S. L. Chauhan and R. A. Bondre, "Partial Replacement of Sand by Quarry Dust in Concrete," vol. 5, no. 7, pp. 5-8, 2015.

12. Beauro of Indian Standards, IS:383-1970-Specification For coarse and fine aggregates from natural sources for concrete. 1970.

13. Beauro of Indian Standards, Concrete Mix Proportioning Guidelines (First Revision). 2009.

14. B. M. Mithun, M. C. Narasimhan, N. Palankar, and A. U. Ravishankar, "Flexural Fatigue performance of Alkali Activated Slag Concrete mixes incorporating Copper Slag as Fine Aggregate," vol. 10, no. 1, pp. 7-18, 2015.

15. Beauro of Indian Standards, "IS-456-2000-Plain-ReinfConcrete" 2000.

16. Beauro of Indian Standards, IS 516-1959:Indian Standard Methods of Tests- for Strength of Concrete. 1959.

\section{AUTHORS PROFILE}

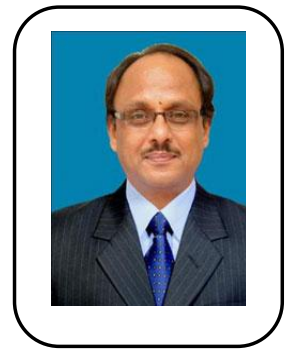

Dr. I.R. Mithanthaya finished his B.E in Civil Engineering from Govt. B.D.T. College of Engineering Davangere during the year 1983-1984. During 1989-1991, he did his M. Tech in Industrial Structure from N.I.T.K Surathkal. From 2000 to 2003 he worked as Asst. Professor in Civil Engineering Department of Bahir
Dar University, Ethiopia. He completed his M.B.A Degree through Karnataka Open University during the year 2004 in Human Resource Management. From 2003 to 2007 he worked as Associate Prof. and Head of Civil Engineering, NMAMIT, Nitte. He obtained his doctorate degree from NITK Surathkal for his thesis "Performance studies of Enzyme stabilized soils" during February 2011. He is a member of various professional bodies such as Indian Society for Technical Education (ISTE), Institution of Engineers India (IEI), Indian Geotechnical society (IGS), Fellow of Indian Valuver (FIV) and Indian Road Congress (IRC). Dr. Mithanthaya worked as Coordinator for World Bank project Technical Education Quality Improvement Programme (TEQIP) Phase I which is 12.5 Crores project sanctioned to NMAMIT, Nitte. He was also Coordinator for TEQIP project Phase II which was 4.00 Crore project which mainly focused on Research development at NMAMIT, Nitte. Dr. Mithanthaya has published more than 10 technical papers in National \& International journals. He has presented 30 papers in National \& International Conferences. Dr. Mithanathaya visited countries like Canada, Italy, Sri lanka and Japan on different assignments. He has more than 30 years of teaching experience. He has guided more than $25 \mathrm{M}$. Tech projects and presently guiding $5 \mathrm{Ph}$. D. students. From, Feb.2007 to June 2012 Dr. Mithanthaya worked as Chief Project Leader of Entrepreneur Development Cell of NMAMIT, Nitte. From July 2012, Dr. Mithanthaya has taken the charge as Vice Principal \& Dean (Academics) of NMAMIT, Nitte.

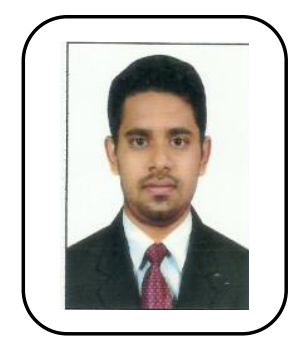

Mr. Shriram Marathe is currently working as an Assistant Professor in the Department of Civil Engineering, NMAM Institute of Technology, Nitte. He has completed his BE in Civil Engineering in the year 2012 from NMAMIT and M. Tech in Transportation Engineering from NITK Surathkal in the year 2014. He is currently pursuing his doctoral study at VTU, Belagavi under the guidance of Dr. I R Mithanthaya. He has also completed his post graduate degree in Human Resource Development from College of Leadership and Human Resource Development, and he is a certified soft skill trainer in HRD. He has about 5 years of teaching experience. Till date, he has guided 17 B.E. project dissertation, 5 M. Tech project dissertation. He has attended more than 20 workshops and technical sessions. He has published over 27 papers in reputed national and international journals and conferences. He also delivered few technical talks as a resource person in technical seminars. He also has the experience of co-ordinating few core departmental committees such as NAAC, NBA, IQAC, and Industry Institute Interaction.

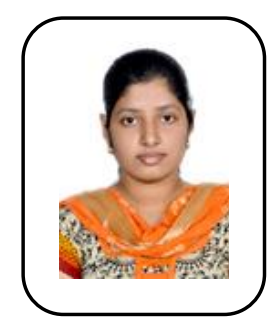

Ms. Sahithya S Shetty is currently pursuing her M. Tech in Structural Engineering in NMAM Institute of Technology, Nitte. She has completed her BE from Shri Madhwa Vadiraja Institute of Technology \& Management, Bantakal in the year 2017. She has published 3 papers in reputed national and international journals and conferences. She has attended 7 workshops and technical sessions. 